\title{
PEMBERIAN HUKUMAN POSITIF GURU BIMBINGAN KONSELING DI SMPN 1 KALASAN YOGYAKARTA
}

\begin{abstract}
Taslima
Pascasarjana UIN Sunan Kalijaga Yogyakarta, Afiliasi Penulis2 taslima830@yahoo.com

Received:

; Accepted:

; Published :

Abstract: School is a formal institution that has an order that must be obeyed. There are various penalties given by the teacher in school so that students do not repeat the same mistakes in the future. Today there are still many educational institutions giving negative penalties. This article examines the positive punishment given by counseling teachers to deal with the indiscipline of students at Kalasan 1 Public Middle School. The purpose of this article is to understand what penalties and types of positive punishment given by the $B K$ teacher to their students. This article concludes that the positive punishment given by counseling tutors at 1 Kalasan Middle School is aimed at training discipline.
\end{abstract}

Keywords: Discipline, punishment, counseling.

Sekolah merupakan lembaga formal yang memberikan pengajaran terprogram dalam rangka menciptakan dan melatih semua siswa untuk mengembangkan potensi yang dimilikinya. Sekolah salah satu lembaga pendidikan tempat belajar di mana peserta didik akan dibina membina, mengembangkan dan menyempurnakan potensi dirinya serta dunia kehidupan dan masa depanya. Di sekolah guru juga mempersiapakan generasi muda menjadi manusia yang dewasa dan berbudaya. Maka dapat dipahami bahwa sekolah merupakan salah satu lembaga pendidikan formal yang berupaya membinapeserta didik menjadi anak yang berguna bagi bangsa dan negara. Siswa yang merupakan generasi penerus, maka guru harus benar-benar fokus untuk menciptakan prestasi yang unggul pada setiap siswa yang memiliki kemampuan yang unik pada setiap dirinya. Pesera didik juga merupakan pribadi yang sedang dalam masa proses berkembang kearah yang lebih dewasa. Juga setiap individu memiliki karakter yang berbeda-beda dan unik, setiap siswa mempunyai kemampuan, emosi, kecerdasan dan kebiasaan yang berbeda-beda. Dan siswa-siswipun tidak pernah terlepas dari berbagai masalah yang dialaminya, dari masalah pribadi hingga keluarga, maka tidak jarang terlihat banyak kasus penyimpangan yang terjadi di dunia pendidikan. Program-program pengajaran yang dijalankan di 
sekolah tentunya sudah disesuaikan dan terstruktur berdasarkan tujuan pendidikan yang ada. Melalui proses pengajaranlah seluruh potensi seperti: kejujuran, sopan santu, kedisiplinan, dan tanggung jawab yang ada pada diri anak akan terbentuk dan terbina dengan baik di sekolah. Penanaman tata tertib pada siswa sebagai mana generasi muda memang sagatlah penting. Sekolah sebagai lembaga pendidikan formal yang juga sebagai sarana pendidikan nilai moral dan norma bagi siswa, tentunya mempunyai hukum atau aturan yang dapat membatasi setiap prilaku siswa. Maka tata tertib dapat diartikan sebagai hukum atau aturan yang diterapkan dan di jalankan di sekolah, dan peraturan yang mengatur segenap tingkah laku para siswa selama mereka bersekolah untuk menciptakan suasana yang mendukung pendidikan.

Keberadaan tata tertib di sekolah dapat berfungsi sebagi pedoman berperilaku bagi peserta didik selama mereka di sekolah. Dalam lingkungan sekolah tata tertib di perlukan untuk menciptakan kehidupan sekolah yang tertib, tenteram, kondusif dan penuh dengan kedisiplinan. Kedisiplinan selalu menjadi hal yang banyak dibicarakan oleh banyak orang, baik itu disiplin dalam keluarga, masyarakat maupun sekolah. Terutama sekali disiplin yang ada dalam suatu lembaga pendidikan/ sekolah, karena di sekolah jelas sekali ada peraturan yang dimuat untuk mendisiplinkan peserta didik di sekolah. Hal ini tentu saja tidak lepas dari seorang anak didik dan pendidikanya, terutama para pendidik/guru, sebab disiplin sangat pempengaruhi keberhasilan seorang guru dalam mendidik, dengan mendidik dapat menjadikan seorang anak lebih bertanggung jawab atas segala tindakanya yang menyimpang dan dapat membuat anak didik lebih menghargai waktu dengan baik, Sehingga keberhasilan proses belajar mengajar dapat terlaksan dengan baik. Oleh karena itu dalam menanamkan kedisiplin di sekolah, guru harus memulai dari dirinya sendiri dalam berbagi tindakan dan perilakunya. Timbulnya kesadaran siswa akan kewajibanya untuk memenuhi tata tertib sekolah diharapkan tertanam pada prilaku atau moral siswa di sekolah.

Pendidikan bertujuan untuk mengembangkan potensi agar peserta didik memiliki keterampilan hidup juga bertujuan menjadikan peserta didik memiliki spiritualitas dan akhlak. Pendidikan dalam islam secara substansial adalah pembentukan kepribadian berdasarkan ajaran islam, yang cenderung pemindahan ilmu (pembelajaran) (Ghazali, 2011) . Untuk menunjang tujuan tersebut, maka tentunya harus adanya kerja sama antara guru dan personil sekolah, dan adanya kerja sama antara orangtua, dan siswa. Maka kemampuan dan kualitas setiap guru sangat 
berpengaruh untuk menciptakan penerus yang cerdas. Salah satu guru yang berperan penting dalam membantu mengembangkan potensi tersebut adalah guru bimbingan konseling. Karena di dalam dunia pendidikan perkembangan anak-anak menuju remaja dan selanjutnya menuju ke perkembangan dewasa. Maka siswa harus benar-benar diberikan berbagai bimbingan oleh guru bimbingan konseling. Bimbingan merupakan suatu proses pemberian bantuan kepada individu maupun kelompok orang secara terus menerus dan sistematis oleh guru pembimbing agar individu maupun sekelompok individu menjadi pribadi yang mandiri (Sukardi, 2000). Sedangkan konseling merupakan salah satu teknik dalam pelayanan bimbingan dimana proses pemberian bantuan itu berlangsung melalui wawancara dalam serangkaian pertemuan langsung dan tatap muka antara guru pembimbing / konselor dengan klien dengan tujuan agar klien itu mampu memperoleh pemahaman yang lebih baik terhadap dirinya, mampu memecahkan masalah yang dihadapinya dan mampu mengarahkan dirinya untuk mengembangkan potensi yang dimiliki ke arah perkembangan yang optimal, sehingga ia dapat mencapai kebahagiaan pribadi dan kemanfaatan sosial (Hallen, 2002).

Menurut Soeparman, bimbingan konseling adalah proses bantuan yang diberikan kepada seseorang agar ia mampu memahami diri, menyesuaikan diri dan mengembangkan diri sehingga mencapai kehidupan yang sukses dan bahagia (Soeparman, 2003). Jadi layanan bimbingan konseling yang merupakan bantuan dan arahan yang diberikan oleh konselor kepada klien untuk mengembangkan potensi dan mengenalkan dirinya secara mandiri dengan cara tatap muka antara konselor dan klien. Maka dari itu sekolah harus benar-benar memperhatikan keberadaan guru bimbingan dan konseling di sekolah, dan pemberian bantuan yang terus menerus dari seorang pembimbing yang telah dipersiapkan kepada individu yang membutuhkannya dalam rangka mengembangkan seluruh potensi yang dimilikinya secara optimal dengan menggunakan berbagai macam media dan teknik bimbingan dalam suasana asuhan yang normatif agar tercapai kemandirian sehingga individu dapat bermanfaat baik bagi dirinya sendiri maupun bagi lingkungannya.

Seperti pendapat Nursalim Mochamad, ada beberapa peran konselor di sekolah, yaitu konselor sebagai pewawancara, konselor sebagai konsultan, konselor sebagai agen perubahan, konselor sebagai agen pencegahan, konselor sebagai coordinator, konselor sebagai pemberi motivasi dan konselor sebagai sebagai agen orientasi, dari beberapa 
peran tersebut, yang sangat berpenagruh adalah pemberian motivasi, peran konselor sebagai motivator juga sangat dibutuhkan dalam dunia pendidikan. Karena dengan adanya berbagai motivasi sehingga siswa semakin semangat dalam belajar mengikuti pembelajaran (Mochamad, 2015). Maka guru bimbingan konseling mempunyai peran penting dalam menangani masalah siswa,termasuk diantaranya adalah masalah kedisiplinan. Adapun manfaat adanya guru bimbingan konseling Cara menangani masalah tersebut berbeda, antara satu sekolah dengan sekolah lainnya. Ada yang memberikan hukuman bersifat positif dan ada bersifat negatif. Hukuman negatif adalah hukuman yang menggunakan kerasan fisik dan yang membuat sesorang trauma akan perlakuan yang tidak menyenangkan dari gurunya. Contoh pemberian hukuman negatif, misalnya menskores siswa, keliling lapangan, dan lain sebagainya. Sedangkan hukuman positif adalah yang bermanfaat pada diri siswa.

Menurut M. Ngalim Purwanto punishment (hukuman) adalah penderitaan yang diberikan atau ditimbulkan dengan sengaja oleh seseorang (orang tua, guru, dan sebagainya) sesudah terjadi suatu pelanggaran,kejahatan atau kesalahan (Purwanto, 2006). Sedangkan menurut menurut Syaiful Bahri Djamarah, hukuman merupakan salah satu alat pendidikan yang juga diperlukan dalam pendidikan (Bahri, 2010). Hukuman diberikan sebagai akibat dari pelanggaran kejahatan, atau kesalahan yang dilakukan untuk anak didik. Tidak seperti akibat yang ditimbulkan oleh ganjaran, hukuman mengakibatkan penderitaan atau kedukaan bagi anak didik yang menerimanya. Hukuman dijadikan sebagai suatu motivasi maupun alat pendorong. Siswa yang pernah mendapatkan punishment (hukuman) karena tidak disiplin si sekolah, maka ia akan berusaha untuk tidak memperoleh punishment (hukuman) lagi. Siswa berusaha untuk dapat mengikuti aturan sekolah agar terhindar dari punishment (hukuman). Punishment (hukuman) dalam bidang pendidikan merupakan salah satu bentuk alat motivasi yang digunakan pendidik untuk memperbaiki tingkah laku yang tidak sesuai dengan norma-norma yang diyakini dengan jalan melemahkan perilaku, dilaksanakan sesuai dengan prinsipprinsip pemberian punishment (hukuman) secara tepat dan bijaksana. Tujuan yang dapat dicapai dengan adanya punishment (hukuman) adalah sagar peserta didik yang melakukan pelanggaran tersebut dapat memperbaiki perbuatan serta tingkah 
lakunya yang tidak baik dan diharapkan untuk tidak mengulangi pelanggaran yang pernah dilakukannya.

Adapun beberapa bentuk hukuman yang ada di sekolah, yang pertama hukuman fisik,misalnya dengan mencubit, menampar, memukul dan lain sebagainya. Kedua, hukuman dengan kata-kata atau kalimat yang tidak menyenangkan, seperti omelan, ancaman, kritikan, sindiran, cemoohan dan lain sejenisnya. Ketiga, hukuman dengan stimulus fisik yang tidak menyenangkan, misalnya menuding, memelototi, mencemberuti dan lain sebagainya. Ke empat, hukuman dalam bentuk kegiatan yang tidak menyenangkan, misalnya disuruh berdiri di depan kelas, dikeluarkan dari dalam kelas, didudukan di samping guru, disuruh menulis suatu kalimat sebanyak puluhan atau ratusan kali, dan lain sebagainya.

Sedangkan Keunggulan utama dari hukuman bahwa pemakaiannya dengan tepat akan dapat menghentikan dengan segera tingkah laku siswa yang mengganggu jalannya kegiatan belajar mengajar. Seorang siswa yang mengganggu jalannya kegiatan jalannya kegiatan belajar mengajar, dengan sendirinya akan tidak mengganggu lagi bila hukuman dengan menyuruhnya keluar dari kelas. Tetapi pada sisi lain, hukuman mengandung kelemahan berupa sejumlah akibat sampingan yang negatif. Akibat -akibat negatif yang dapat terjadi antara lain, yang pertama hubungan antara guru dan siswa menjadi terganggu, misalnya siswa mendendam pada guru. Kedua, siswa menarik diri dari kegiatan belajar mengajar, misalnya tidak mau mendengarkan pelajaran. Ketiga, siswa melakukan tidakan-tindakan agresif, misalnya merusak fasilitas sekolah. Keempat, siswa mengalami gangguan psikologis, misalnya rasa rendah diri (Hasibuan.J.J, 1988).

Seni memberi hukuman terhadap anak didik sebagaimana diungkapkan olehTondowidjojo (Tondowidjojo, 1991), bahwa hukuman-hukuman itu seharusnya jarang diberikan, dan harus diseleksi terlebih dahulu serta harus dipertanggung jawabkan. Ini berarti kita tidak boleh menetapkan atas dasar kebencian atau rasa balas dendam. Supaya hukuman-hukuman itu bisa dipertanggung jawabkan, kita harus menjatuhkannya sedemikian rupa sehingga 
betul-betul mengakibatkan perbaikan atas kesalahan-kesalahan yang diperbuatnya. Beberapa sikap pendidik yang tidak dipertanggung jawabkan ialah dengan memuji anak didik yang sombong, menegur anak didik yang rakus, yang menyalin bacaan dengan tulisan yang tidak terang, selama istirahat melarang anak didiknya untuk berbuat sesuatu dan lain sebagainya. Umpamanya lagi ada seorang ibu yang merusak permainan anaknya sebagai hukuman terhadap anaknya yang telah merusak permainan anak yang lain. Hukuman-hukuman tersebut tidak hanya berupa siksaan jasmaniah saja, yang penting harus mampu memberi semangat dan menimbulkan sikap untuk memperbaiki diri. Inilah suatu hal yang harus dipikirkan dalam memberikan suatu obat yang mujarab atau suatu suntikan yang konstruktif kepada anak didik. Apabila tindakan kita tidak mampu menyembuhkan berarti jasa atau pengabdian kita menjadi hilang dan siasia.

Oleh karena itu, hukuman-hukuman yang kita berikan harus merupakan suatu perbaikan yang menyeluruh, serta harus menjajikan suatu kesempatan untuk bangun kembali dan untuk merehabilitasi diri. Hukuman-hukuman yang dijatuhkan harus juga bersifat psikologis. Kita sebaiknya memperhatikan dengan seksama bahwa sebenarnya apa yang bagi kita merupakan satu siksaan atau ganjaran, tidak selalu demikian bagi anak didik. Oleh karena itu, kita harus benarbenar mengenal pribadi anak didik supaya hukuman yang akan diterapkan dapat tepat dan konstruktif. Dari hal tersebut di atas, kita dapat melihat betapa dibutuhkan rasa cinta kasih yang mendalam dari pendidik di dalam menerapkan hukuman itu. Suatu hukuman yang dijatuhkan pada tempat dan waktu yang tepat, yang disertai pula dengan membeda-bedakan akan lebih membimbing dan efektip hasilnya, selain itu hal ini akan lebih diterima dengan baik oleh anak didik.

Beberapa persyaratan pemberian hukuman yang terpenting bagi siswa, Pemberian hukuman harus menimbulkan keinsyafan dan penyesalan pada anak. Inilah yang merupakan hakikat dari tujuan pemberian hukuman. Dengan adanya hukuman, anak harus merasa insyaf dan menyesali perbuatan-perbuatannya yang salah itu, dan dengan keinsyafan ini anak bejanji di dalam hatinya untuk tidak mengulangi perbuatannya lagi. Pemberian hukuman harus menimbulkan kesan pada hati anak. Dengan adanya kesan itu, anak akan selalu mengingat pada 
peristiwa tersebut dan kesan itu akan selalu mendorong anak kepada kesadaran dan keinsyafan, tetapi sebaliknya hukuman tersebut tidak boleh menimbulkan kesan negatif pada anak. Dan Pemberian hukuman harus tetap dalam jalinan cinta kasih sayang. Kita memberikan hukuman kepada anak, bukan karena ingin menyakiti hati anak, bukan karena ingin melampiaskan rasa dendam dan sebagainya. Kita menghukum anak demi untuk kebaikan, demi kepentingan anak, demi masa depan dari anak. Oleh karena itu, sehabis hukuman itu dilaksanakan, maka tidak boleh berakibat putusnya hubungan cinta kasih sayang tersebut (Indrakusuma, 1973)

Jadi semua jenis hukuman baik itu positif maupun negatif tetap dinamakan hukuman, yang membedakan itu adalah cara guru melaksana hukuman tersebut, yang patut digunakan untuk mendidik siswanya menjadi lebih baik dari sebelumnya, tanpa ada rasa kekecewaan disaat menerima hukuman. Ini sama seperti pendapat Skinner dalam teori behavior bahwa seseorang akan berubah menjadi lebih baik dari sebelumnya dikarenakan telah belajar dari berbagai kesalahan. Tetapi yang sering terjadi pada saat ini berdasarkan pengamatan penulis dari beberapa artikel, bahwa hukuman yang sering diberikan adalah hukuman fisik, seperti keliling lapangan, fokus penelitian adalah mengenai pemberian hukuman positif oleh guru bimbingan konseling untuk menangani ketidakdisiplinan siswa di SMPN 1 Kalasan. Artikel ini akan menjawab pertanyaan hukuman apa saja yang diberikan, dan mengapa diberikan berbagai hukuman yang bersifat positif.

\section{Kajian Literatur}

Ada beberapa artikel jurnal yang meneliti mengkaji hukuman negatif di antaranya yaitu penelitian dari Acep Supriadi, Mariatul Kiftiah, menulis artikel berjudul "Efektivitas Pemberian Sanksi Bagi Siswa Pada Pelanggaran Tata Tertib Di Smp 2 Kapuas Timur Kabupaten Kapuas”. Artikel ini menjelaskan bagaimana efektivitas pemberian sanksi pada pelanggaran tata tertib di sekolah. Bentuk sanksi yang ditetapkan pada siswa yang melanggar tata tertib SMP N 2 Kapuas timur adalah sanksi fisik dan sanksi administeratif. Sanksi fisik terdiri dari lari mengelilingi lapangan, membersikan lingkungan sekolah dll. Sedangkan sanksi administertif terdiri dari peringatan, teguran, nasehat, dipanggil orang tua, di skorsing dan di kembalikan kepada orang tua 
(dikeluarkan), kendala di sekolah sering kali tidak di jalankan oleh para siswa dan seorang gurupun tidak bisa mengonterol siswa semua dalam hal ini yang sering dilakukan oleh siswa seperti pelanggaran meroko, membawa hp dan membawa sepeda motor kesekolah dll hal ini terlihat ketika peneliti melihat sendiri, adapun siswa yang membawa motor seringkali tidak diparkir di lingkungan sekolah bahkan di parkir di rumah orang dan warung-warung yang dekat dengan sekolah. Kendala yang dihadapi sekolah dalam memberikan sanksi terhadap siswa yang melanggar tata tertib sekolah yaitu jumlah siswa yang terlalu banyak sementara penaggung jawab keiswaan sedikit. Ketidak seimbangan tersebut membuat kesiswaan tidak dapat memperhatikan siswa yang melanggar tata tertib sekolah. Pihak sekolah melakukan berbagai upaya untuk mengataasi kendala-kendala tersebut seperti melaksankan teguran dan melakukan sosialisasi secara rutin. (Supriadi \& Kiftiah, 2014).

Selanjutnya artikel Berjudul "Efektifitas Ta'zir Dalam Meningkatkan Kedisiplinan Santri Di Pondok Pesantren Daarun Najaah Jerakah Tugu Semarang”. Artikel ini menjelaskan bermacam-macam sangsi yang diberikan jika anak melanggar tata tertib di pondok. Apabila dengan sengaja menghina dan menantang pengasuh maka akan dikeluarkan dengan tidak hormat. Santri yang tidak memenuhi kewajiban administrasi, akan diperingatkan. Santri yang menemui tamu tanpa izin dan diketahui tamu itu adalah kekasih maka akan mendapatkan hukuman membersihkan selokan. Tidak mengikuti sholat jama'ah lima waktu, maka harus membayar denda, membersihkan bak wudhu. Indek Prestasi (IP) turun, maka harus infak satu sak semen.

Kedisiplinan santri di pondok pesantren Daarun Najaah tidak samuanya berjalan, mengingat para santri adalah rata-rata para mahasiswa yang dilatarbelakangi oleh perbedaan daerah asal, lingkungan sebelum menjadi santri dan keadaan ekonomi akan menghadapi keragaman dalam hal kualitas kedisiplinan pada tata tertib pondok pesantren. Derajat kualitas kedisiplinan santri pondok pesantren Daarun Najaah ada yang sudah biasa disiplin, dan ada juga yang belum terbiasa untuk disiplin terhadap tata tertib pondok pesantren. Ta'zir yang ada di pondok pesantren daarun Najaah sangat efektif untuk meningkatkan kedisiplinan santri. Contohnya kedisiplinan dalam belajar seperti IP (indeks prestasi) turun. Setelah santri tersebut mendapatkan ta'zir karena IPnya turun, maka santri akan belajar lebih rajin agar IP-nya naik dan tidak mendapatkan ta'zir lagi. Untuk meningkatkan kedisiplinan dalam beribadah 
seperti tidak melaksanakan salat wajib berjama'ah, salat dzuha, salat malam, dan ibadah-ibadah lainnya yang telah ditetapkan dalam tata tertib pondok, Maka setelah santri tersebut mendapatkan ta'zir karena perbuatanya, santri akan berusaha untuk melaksanakan ibadahibadah tersebut dengan baik. Untuk meningkatkan kedisiplinan dalam mentaati peraturan lainnya, maka setelah santri mengetahui dan menyadari akan kesalahannya, santri tidak akan melanggarnya dan akan berusaha selalu mematuhinya (Rofi, 2008).

Selanjutnya skripsi mengenai "Hubungan Religiusitas Dengan Kedisiplinan Santri Pada Madrasah Tsanawiyah Pondok Pesantren Iqra”. Skripsi ini menjelaskan berbagai macam jenis hukuman yang ada dipondok adalah sebagai berikut, yang apabila mendapat hukuman berat, maka akan didatangkan orang tuanya ke pondok, kerja bakti, melaksanakan ibadah amaliyah, serta denda sesuai dengan pelanggaran. Jika mendapatkan hukuman sedang, maka membaca sholawat nariyah, kerja bakti, dan membayar denda, apabila mendapatkan ukuman ringan, maka harus kerja bakti dan membayar denda. Juga hasil penelitian ini menyatakan ada hubungan yang signifikan antara tingkat religiusitas dengan kedisiplinan pada santri Pondok Pesantren Al Hidayah

Purwojati Banyumas. Dengan korelasi sebesar 0,643 yang berarti korelasi tersebut termasuk kategori kuat. Hal ini sesuai dengan teori, semakin tinggi tingkat religiusitas santri maka semakin tinggi juga kedisiplinannya, sebaliknya semakin rendah kedisiplinan santri maka semakin rendah juga tingkat religiusitasnya (Suharti, 2018).

Selanjutnya artikel yang berjudul “. Penelitian ini bertujuan untuk memperoleh data mengenai implementasi pemberian reward dan punishment dalam membentuk karakter disiplin anak usia dini pada kelompok B di RA AnNawaa 3 Kota Cirebon. dalam rangka dalam rangka mendisiplinkan anak usia dini khususnya pada kelompok B guru menggunakan beberapa strategi diantanya pemberian reward dan punishment. Hasil dari penelitian ini adalah Implementasi pemberian reaward dan punishment dalam membentuk karakter disiplin anak usia dini khususnya pada kelompok B dalam penerapannya RA AnNawaa 3 memberikan sebuah reward ketika anak melakukan suatu tindakan baik dan memberikan punishment ketika anak melakukan suatu tindakan kurang baik yang melanggar peraturan tata tertib dalam penerpan pemberiannya RA AnNawaa 3 selalu mempertimbangkan usia serta situasi dan kondisi agar 
pemberian reward dan punishment sesuai dengan kebutuhan. Adapun bentuk reward yang diberikan kepada anaknya yaitu reward verbal dan non verbal sedangkan untuk punishmentnya guru hanya memberikan punishment verbal (Sabartiningsih, 2018).

Skripsi yang berjudul "Penerapan Reward Dan Punishment Dalam Pembelajaran Pai Dan Dampaknya Terhadap Motivasi Belajar Di Pm. Ar-Risalah Slahung Ponorogo Tahun 2016". Penelitian ini dilakukan dengan tujuan, untuk mengetahui penerapan (Reward dan Punishment) dalam pembelajaran PAl di Pondok Modern Ar-Risalah Slahung, Ponorogo. Untuk mengetahui dampak penerapan (Reward dan Punishment) dalam pembelajaran PAl terhadap motivasi belajar santri di Pondok Modern Ar-Risalah Slahung, Ponorogo. Dari hasil temuan penelitian ini, bahwa penerapan reward and punishment dalam pembelajaran PAl peserta didik MTs Ar-Risalah Slahung Ponorogo harus sesuai dengan peraturan yang sudah disepakati. Dalam memberikan reward and punishment pendidik diharapkan melakukannya dengan adil, tidak membedakan status/ golongan, dan tidak ada unsur balas dendam yang dapat menyakiti peserta didik. Setiap pendidik berhak memberikan reward and punishment dengan carater sendiri, yang penting masih dalam hal yang wajar dan harus ada unsur mendidik yang dapat menjadikan santri termotivasi untuk menjadi lebih baik. Reward and punishment ini diterapkan dengan tujuan menjadikan peserta didik terarah padahal kebaikan, sehingga metode ini bisa digunakan sebagai alat pendidikan yang efektif yang dapat membawa perubahan pada peserta didik untuk menjadi lebih baik. Bahwa dengan reward \& punishment dapat membawa dampak yang positif pada peserta didik. Karena mereka bisa menjadi lebih baik, baik dalam pelajaran maupun kegiatan yang lain yang dapat memupuk akhlak mereka untuk mengarah pada akhlak yang terpuji (Watoni, 2016).

Selanjutnya artikel yang berjudul "Pengaruh Reward And Punishment Terhadap Kedisiplinan Siswa Kelas Tinggi Sd Negeri 3 Pandean Kecamatan Ngemplak Kabupaten Boyolali Tahun Ajaran 2014/2015". Penelitian ini bertujuan untuk mengetahui pengaruh reward terhadap kedisiplinan siswa kelas tinggi SD Negeri 3 Pandean Kecamatan Ngemplak Kabupaten Boyolali Tahun Ajaran 2014/2015, mengetahui pengaruh punishment terhadap kedisiplinan siswa kelas tinggi SD Negeri 3 Pandean Kecamatan Ngemplak Kabupaten Boyolali Tahun Ajaran 2014/2015, mengetahui pengaruh reward and punishment terhadap kedisiplinan siswa kelas tinggi SD 
Negeri 3 Pandean Kecamatan Ngemplak Kabupaten Boyolali Tahun Ajaran 2014/2015. Hasil penelitian menunjukkan:1) Ada pengaruh reward terhadap kedisiplinan siswa kelas tinggi SD Negeri 3 Pandean Kecamatan Ngemplak Kabupaten Boyolali Tahun Ajaran 2014/2015. Berdasarkan uji t memperoleh thitung > ttabel (5,25> 2,35). 2) Ada pengaruh punishment terhadap kedisiplinan siswa kelas tinggi SD Negeri 3 Pandean Kecamatan Ngemplak Kabupaten Boyolali Tahun Ajaran 2014/2015. Berdasarkan uji t memperoleh thitung > ttabel $(5,46>2,35)$. 3) Ada pengaruh reward and punishment terhadap kedisiplinan siswa kelas tinggi SD Negeri 3 Pandean Kecamatan Ngemplak Kabupaten Boyolali Tahun Ajaran 2014/2015. Berdasarkan uji F memperoleh Fhitung > Ftabel (3,53> 3,33) (Suwarno dan Lathifah Arifatul Farida, 2916).

\section{METODE}

Penelitian artikel ini adalah penelitian lapangan yang bersifat deskriptif kualitatif yaitu menganalisa dan menyajikan fakta secara sistematik tentang objek yang sebenarnya. Sugiyono, mengartikan penelitian kualitatif adalah, penelitian naturalistik, karena penelitiannya dilakukan pada kondisi yang alamiah. Dalam penelitian kualitatif pengumpulan data tidak dipandu oleh teori, tetapi dipandu oleh fakta-fakta yang ditemukan pada saat penelitian dilapangan (2015). Sedangkan Margono mengemukakan bahwa penelitian kulitatif adalah prosedur penelitian yang menghasilkan data deskriptif berupa kata-kata tertulis atau lisan dari orang-orang dan perilaku yang diamati(2010). Subjek penelitian ini adalah guru bimbingan dan konseling. Penelitian ini hanya menggambarkan keadaan yang ada dilapangan yaitu keadaan pada saat penelitian dilakukan,dan data yang diperlukan adalah bersifat informasi dan keterangan. Adapun metode yang digunakan adalah observasi, melihat langsung disaat guru Bk memberikan hukumna kepada siswa disekolah, dan wawancara dilakukan dengan guru Bk, sedangkan dokumentasi yaitu buku melihat buku penangan masalah di sekolah.

\section{PEMBAHASAN}

Hasil observasi dan wawancara dengan guru bimbingan dan konseling mengenai kedisiplinan di sekolah menunjukkan bahwa, siswa yang datang terlambat, sangat sedikit dan jarang. Jika ada siswa yang datang terlambat ke sekolah maka dia akan mendapatkan hukuman. Berdasarkan hasil observasi di SMPN 1 Kalasan, terlihat lingkungan sekolah yang sangat tertib ketika jam pelajaran berlangsung, tidak ada satu siswa berkeliaran main-main di halaman maupun di kantin. Mereka tertib menunggu guru datang ke kelas 
disaat jam pergantian mata pelajaran. Di saat jam siang terlihat ada siswa yang di halaman, tujuan mereka keluar dari ruangan kelas adalah untuk menuju ke masjid yang berada di lingkungan sekolah. Mereka melakukan sholat zuhur, setelah waktu shalat zuhur usai, maka siswa siswi kembali masuk ke ruangan untuk belajar.

Hasil observasi dan wawancara, dengan guru bimbingan konseling mengenai kedisiplinan di sekolah menunjukkan bahwa siswa yang datang terlambat kesekolah sangat minim dan jarang. Guru bimbingan konseling di sekolah ini sangat aktif dalam melaksanakan layanan bimbingan klasikal. Pertama, siswa yang terlambat masih boleh masuk, tetapi mendapatkan hukuman di saat pulang. Kedua, jika siswa terlambat sepuluh menit, maka akan di tambah sepuluh menit di saat jam pulang sebagai hukuman. Hukuman bersifat positif, misalnya melakukan tadarus Al- Qur'an selama sepuluh menit di saat jam pulang. Ini memberikan efek positif bagi siswa yang melanggar tata tertib.Kedisplinan yang dilatih oleh guru BK ini merupakan salah satu kunci agar siswa dan siswi terbiasa disiplin. Menurut Tilaar disiplin merupakan sikap yang harus dijadikan kebiasaan dalam hidup baik di sekolah maupun masyarakat. Lembaga pendidikan meletakkan kedisiplinan sebagai hal penting yang merupakan bagian yang tidak terpisahkan dari proses pendidikan. Dan karakter disiplin akan mengalir dari kebiasaan kanak-kanak (Tilaar \& Suwantikno, 2014). Inilah tujuan dari guru BK melatih kedisiplinan agar siswa terbiasa dalam berdisiplin. Pihak sekolah telah sepakat bahwa dalam mendidik siswa di sekolah tidak ada bentuk kekerasan apapun oleh guru. Ketika merancang sebuah program hukuman, guru harus mempertimbangkan efek yang akan terjadi kedepan. Konselor professional harus menyadari bahwa hukuman sering kali tidak sepenuhnnya mengurangi perilaku yang tidak diinginkan (Erford, 2015). Tujuan guru memberikan hukuman adalah agar siswa tidak menggulangi lagi kesalahan yang sama dimasa yang akan datang. Selain itu, hukuman tersebut juga dimaksudkan agar bermanfaat bagi masa depan siswa dalam membiasakan disiplin.

Ketiga, jika ada siswa yang suka usil dan ribut dikelas maka guru tidak serta merta memberikan hukuman fisik seperti menjewer dan push up,guru meminta siswa duduk disampingnya untuk mendengar kanmateri yang di sampaikan. Ini dilakukan agar siswa lebih serius mengikuti pelajaran. Jika siswa tersebut sudah bisa serius mengikuti pelajaran di samping guru, maka dia di persilahkan duduk di posisinya. Siswa bukan 
hanya sekedar duduk disamping guru guru bimbingan di depan. Dia juga dibina dan dibimbing agar bisa tenang mengkuti palajaran. Hal ini memberikan pemahaman kepada siswa, bahwa jika ruangan kelas tenang maka semua siswa dapat mengikuti pelajaran dengan baik. Sebagaimana di katakan Dewa Ketut bahwa tugas BK adalah untuk membimbing siswa ke arah yang lebih baik dan memperbaiki tingkah laku yang tidak baik menjadi baik di masa yang akan datang (Dewa Ketut, Nila, 2008).

Selanjutnya jika guru bimbingan konseling melihat siswa siswinya berpakaian tidak rapi, dia menegur mereka, guru tidak akan menegur di depan kelas ataupun temannya, tetapi memanggilnya ke ruangan bimbingan konseling untuk merapikan baju. Jika mengulanginya lagi maka siswa itu diminta untuk merapikan di depan kelas. Ini bertujuan untuk melatih siswa agar selalu rapi dalam berpakaian di lingkungan sekolah. Jika ada siswa tidak rapi, maka guru bimbingan konseling tidak segan-segan untuk memanggilnya keruangan bimbingan konseling. Ketika siswa siswi sedang merapikan baju, maka guru bimbingan konseling tetap memberikan bimbingan dan nasehat. Ini semua bertujuan untuk melatih siswa siswi menjadi orang yang disiplin dalam berpakaian, jadi menurut guru bimbingan konseling hukuman yang bersifat positif itu diberikan melalui teguran secara halus, tetapi bermanfaat bagi mereka, agar tidak mengulangi kesalahan dimasa yang akan datang. Jika siswa siswi dilatih dengan terus menerus dan berefek positif maka anak tersebut tidak ada rasa kesal ataupun marah terhadap guru bimbingan konseling. Jika hukuman negatif diberikan maka akan menimbulkan kesan bahwa guru BK galak.

Jadi guru BK di SMPN 1 Kalasan berpendapat bahwa menegur dan memberi hukuman itu bertujuan agar berubah baik di kemudian hari, tidak menimbulkan persepsi bahwa guru bimbingan konseling jahatdan sebagainya. Semua hukuman yang bersifat positif ini bertujuan agar siswa siswi dapat terlatih ber baik dan disiplin. Jika siswa siswi terlatih berdisiplin sejak di sekolah, maka disaat mereka terbiasa berdisiplin di masa dewasa.

Sejalan dengan pendapat Gaza bahwa hukuman yang diberikan kepada siswa siswi maka akan membuahkan hasil positif. Hukuman yang bersifat positif tidak membuat trauma dan sakit hati. Selain itu hukuman yang bersifat positif bisa membuat efek jera. Inilah hukuman yang bersifat mendidik (Gaza, 2012). Dan realita dilapangan sependapat dengan M. Ngalim Purwanto punishment (hukuman) adalah 
penderitaan yang diberikan atau ditimbulkan dengan sengaja oleh seseorang (orang tua, guru, dan sebagainya) sesudah terjadi suatu pelanggaran, kejahatan atau kesalahan (Purwanto, 2006). Jadi hukuman yang diadakan dan diberikan oleh pihak sekolah kepada siswa dilakukan dengan sengaja, dengan tujuan agar siswa terlatih dalam berdisiplin di manapun dan kapanpun.

\section{KESIMPULAN}

Hukuman positif merupakan hukuman yang tidak menggunakan kekerasan fisik maupun teguran yang membuat seseorang itu trauma. Hukuman positif ini adalah hukuman yang tidak menimbulkan kesan yang tidak menyenangkan terhadap siswa siswi. Dalam memberikan hukuman positif, guru tetap mengoreksi kesalahan siswa siswi, namun hukuman positif ini jarang digunakan oleh lembaga pendidikan. Padahal hukuman positif ini sangat memberikan efek positif bagi siswa-siswi di sekolah, karena dengan hal ini mereka lebih merasakan bimbingan dari pada hukuman fisik. Dalam memberikan hukuaman maka sebaiknya guru dapat melihat efek yang terjadi setelah adanya hukuman, apalagi hukumna yang bersifat negatiif kepada peserta didik di sekolah. Karena seperti kita ketahui bahwa hukuman negative tidak akan bertahan lama. Dibandingkan dengan hukuman dengan hukuman positif. Karena jika hukuman positif diberikan kepada siswa maka akan beebekas pada fikiran siswa, karena hukuman positif itu bersifat mendidik ataupun berbentuk bimbingan. Maka dari itu guru bimbingan konseling harus mengetahui lebih banyak dalam mendidik siswa dan mengubah karakter siswa tetap menjadi anak-anak baik dan berakhalak mulia. Maka hukuman ini ditunjukan untuk memperbaiki tingkah laku yang buruk menjadi baik, setelah anak menyadari dan menyesali perbuatan salah yang telah dilakukanya di sekolah.

\section{DAFTAR PUSTAKA}

Bahri, S. (2010). Guru Dan Anak Didik Dalam Interaksi Edukatif. Jakarta: Rineka Cipta. Dewa Ketut, Nila, S., Kusmawati. (2008). Proses Bimbingan dan Konseling di Sekolah. Rineka Cipta. 
Erford, B. T. (2015). 40 Teknik Yang Harus Diketahui Konselor. Yogyakarta: Pustaka Pelajar.

Gaza, M. (2012). Bijak Menghukum Siswa. Yogyakarta: Ar-Ruzz Media.

Ghazali, B. (2011). Pendidikan Islam Untuk Konselor . Yogyakarta: CV. Amanah.

Hallen. (2002). Bimbingan dan Konseling. Jakarta: Ciputat Pers.

Hasibuan.J.J. (1988). Proses Belajar Mengajar. Bandung: Remaja Karya.

Indrakusuma, A. D. (1973). Pengantar Ilmu Pengetahuan. Malang: Fakultas Ilmu Pendidikan IKIP Malang.

Margono. (2010). Metodelogi Penelitian Pendidikan. Jakarta: Rineka Cipta.

Mochamad, N. (2015). Pengembangan Profesi Bimbingan Dan Konseling . Jakarta: Erlangga.

Purwanto, M. N. (2006). Ilmu Pendidikan Teoretis Dan Praktis. Bandung: Remaja Rosda Karya.

Rofi, A. (2008). Efektifitas Ta'zir Dalam Meningkatkan Kedisiplinan Santri Di Pondok Pesantren Daarun Najaah Jerakah Tugu Semarang, 66.

Sabartiningsih, M. (2018). Implementasi Pemberian Reward Dan Punishment Dalam Membentuk Karakter Disiplin Anak Usia Dini Cirebon. AWLADY: Jurnal Pendidikan Anak, 2.

Soeparman. (2003). Bimbingan Konseling Pola 17. Yogyakarta: UCY Press.

Sugiyono. (2015). Memahami Penelitian Kualitatif. Bandung: Alfabeta.

Suharti, N. (2018). Hubungan Religiusitas Dengan Kedisiplinan Santri Pada Madrasah Tsanawiyah Pondok Pesantren Iqra’ Skripsi, 42.

Sukardi, D. K. (2000). Pengantar Pelaksanaan Program Bimbingan Dan Konseling Di Sekolah. Jakarta: Rineka Cipta.

Supriadi, A., Kiftiah, M., \& Agusnadi. (2014). Pemberian Sanksi Bagi Siswa Pada Pelanggaran Tata Tertib Di Smp 2 Kapuas Timur Kabupaten Kapuas., 1.

Suwarno dan Lathifah Arifatul Farida. (2916). Pengaruh Reward And Punishment Terhadap Kedisiplinan Siswa Kelas Tinggi Sd Negeri 3 Pandean Kecamatan Ngemplak Kabupaten Boyolali Tahun Ajaran 2014/2015. Aktualisasi Bimbingan dan Konseling pada Pendidikan Dasar, 2.

Tilaar, H. A. ., \& Suwantikno, T. (2014). Pendidikan Antikorupsi Untuk sekolahdan 
perguruan Tinggi. Jakarta: Indeks.

Tondowidjojo, J. (1991). Kunci Sukses Pendidikna. Yogyakarta: Kansius.

Watoni, A. P. (2016). Penerapan Reward Dan Punishment Dalam Pembelajaran Pai Dan

Dampaknya Terhadap Motivasi Belajar Di Pm. Ar-Risalah Slahung Ponorogo.

Fakultas Agama Islam Universitas Muhamadiyah Ponorogo, 5. 